\title{
COMPARATIVE CHARACTERISTICS OF MECHANICAL AND ADSORPTION PROPERTIES OF ACTIVATED CHARCOALS APPLIED FOR ADSORBERS OF NPP AIR DISCHARGE SYSTEMS
}

\author{
I.V. Lepin, R.M. Sibileva, V.I. Sokolenko, E.I. Vinokurov, M.A. Grigorenko \\ National Science Center "Kharkov Institute of Physics and Technology”, Kharkiv, Ukraine \\ E-mail:vsokol@kipt.kharkov.ua
}

This paper presents the results of studies on the strength and adsorption characteristics of granular activated charcoals of the brand ISQ DON GW4, C40/4 EXTRA KJ, and Norit RKJ4. The ultimate strength of samples was measured in different states: initial $\left(\mathrm{H}_{2} \mathrm{O}\right.$ vapor saturation as a result of long-term storage), dehydrated, $\mathrm{I}_{2}$ vapor saturated and $\mathrm{H}_{2} \mathrm{O}+\mathrm{I}_{2}$ vapor saturated. A significant $(25 \ldots 40 \%)$ decrease in the activated charcoal fracture stress due to the iodine vapor saturation, concerned with a Rehbinder effect, was observed. The degree of the adsorption decrease in the sorbent mechanical stability should be taken into account when selecting sorbents for filters of NPP air discharge purification systems (ventilation systems).

\section{INTRODUCTION}

A successful use of sorbents in different current technologies is determined, for the most part, by their adsorption properties, as well as, by mechanical and structure characteristics, i.e. specific surface, porosity, strength. Of great scientific and practical interest is the study on the change in the properties of sorbents, in particular activated charcoals, during their storage and under operating conditions. As is shown in $[1,2]$ the activated charcoal strength usually decreases under operation conditions. The well-known effect is an activated charcoal "poisoning" with acid gases $\left(\mathrm{CO}_{2}\right.$, $\mathrm{NO}_{2}$, and $\mathrm{SO}_{2}$ ) which always are as impurity in the atmospheric air [3].

The internal sorbent structure - shape and size of pores, anisotropy of their arrangement, total porosity, may have an appreciable influence on the strength characteristics. In general, the increase of the porosity in fragile materials causes the degradation of their strength and elastic characteristics such as ultimate strength, Young modulus, modulus of elasticity in shear, Poisson coefficient [4, 5] (Fig. 1).

The surface-active, liquid and gaseous media exert influence on the strength characteristics of solids in case of surface interaction and absolute absence of the volume diffusion and corrosion effects. The influence of surface-active media on the processes of deformation and fracture of solids as a result of the reversible physical adsorption is known as a Rehbinder effect (1928) i.e. adsorption strength characteristic deterioration. The effect is quite universal and reversible - after medium removal the initial material recovers completely its mechanical properties. This is a distinction of the Rehbinder effect from other medium actions on the mechanical characteristics of solids, in particular, from the dissolution and corrosion processes resulting in the irreversible degradation of not only mechanical properties, but of other functional characteristics too.

For porous highly dispersed materials, including sorbents, a specific medium influence on their properties is characteristic, that is related to the high multibranched surface. The pore space surface grows with porosity increasing, depending on the pore size distribution that intensifies the Rehbinder effect.

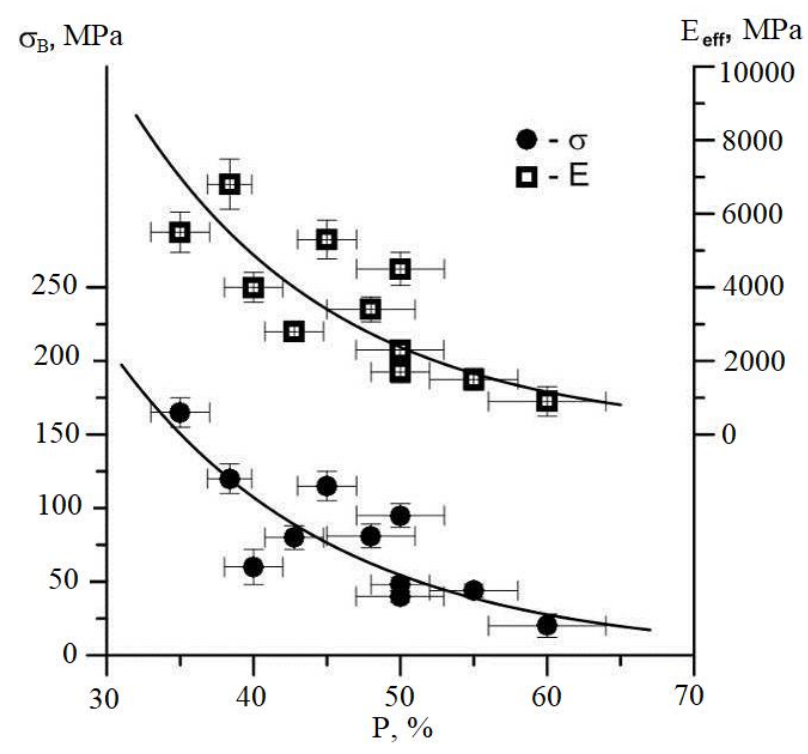

Fig. 1. Ultimate strength $\sigma_{B}$ and Young modulus $E_{\text {eff }}$ versus porosity $P[4,5]$

Adsorption decrease of the macro- and mesoporous solid strength is considered in detail in [6]. The mechanisms of the Rehbinder effect development in microporous adsorbents differ from those discussed in [6]. The causes of this are in the following. Some types of activated charcoals have a high $(75 \ldots 80 \%)$ volume fraction of micropores and their contribution to the surface area exceeds $80 \%$. The rest consists of macroand mesopores which play the role of transport channels. The main parameter, that characterizes microporous adsorbent, is a total micropore volume. Adsorption in such materials is of a volumetric type and approaches to chemisorption.

Adsorption in microporous adsorbents leads to significant change in the properties of both adsorbent and adsorbate. Inside micropores there is a field changing the adsorbate structure, and its properties differ significantly from the properties on the "open" surface (in macro- and mesopores) and from the properties of substance in the equilibrium bulk phase. 
The properties and chemical potential of adsorbent also are changing that does not permit to consider it as an inert substance [7]. The adsorption on the microporous adsorbents is thermodynamically similar to the volume dissolution. The volume filling leads to changing in the properties of the whole adsorbent, not only of the surface layer, as in the case of macro- and mesoporous sorbents. Therefore, the Rehbinder effect in microporous materials will reveal itself more strongly than in macroand mesoporous materials. There is also a work softening effect [8]. These effects play a major role in the microporous material strength decrease.

A purpose of this work was to study the strength characteristics under conditions of uniaxial compression of different-brand charcoal samples to estimate the effect of the system of the pores, formed in the process of charcoal production and filled with adsorbates, on the mechanical stability, nucleation and fracture process development. It has been interesting to study the adsorption change in mechanical characteristics due to the activated charcoal saturation with adsorbates (water vapor and molecular iodine vapor) having a different character of interaction with carbon. Information on these problems is of practical importance, taking into account that air filters, used in the NPP air discharge purification systems (ventilation systems), absorb these substances by activated charcoal, the granules of which are exposed to the lateral von Karman forces. These forces cause the oscillating shear of granules, leading to the granule abrasion.

\section{SAMPLES AND EXPERIMENTAL METHODS}

Charcoals of brands ISQ Don GW4, C40/4 Extra KJ, and Norit RKJ4 were studied. The samples for testing mechanical properties were in the form of visible defectfree cylinders of $(4 \pm 0.1) \mathrm{mm}$ in diameter and $(5 \pm 0.1) \mathrm{mm}$ in length. The specified length of samples and the flatness of faces were provided by the mechanical polishing. The compression testing of samples has been performed at room temperature and loading rate of $10^{-3} \mathrm{~s}^{-1}$. Four types of samples were tested. The first-type (initial) samples were saturated with moisture as a result of a long exposure to the air. The second-type ("dry" or dehydrated) samples were prepared by the vacuum drying $\left(P=10^{-2} \mathrm{~Pa}, T=350{ }^{\circ} \mathrm{C}\right.$ for $2 \mathrm{~h}$ ) of the first-type samples. To prepare the thirdtype samples the first-type samples were saturated with iodine vapors under atmospheric pressure at room temperature. The four-type samples were obtained using the second-type "dry" samples which were saturated with iodine vapors in vacuum at room temperature. A criterion of adsorption saturation of the samples was to reach a zero mass increase.

The ultimate strength $\sigma_{B}$ was calculated as the ratio of fracture force to initial cross-section sample area. To determine the average ultimate strength $\bar{\sigma}_{B}$ the averaging was carried out over no less than five eachtype samples of all the charcoal brands. The meansquare deviation of the ultimate strength $\lambda$ was calculated by standard methods. The adsorption capacitance $a=[\mathrm{g} / \mathrm{g}]$ was determined by the gravimetric method when the adsorption curve reached saturation: $a=\Delta m / m_{0}=\left(m_{a}-m_{0}\right) / m_{0}$, where $m_{a}$ is the mass of the adsorbent completely saturated with the adsorbate; $m_{0}$ is the adsorbent mass after regeneration.

The densities of adsorbate-saturated charcoals were calculated from the formula $\rho=\rho_{0}(a+1)$, where $\rho_{0}$ is the density of dehydrated charcoal, $a$ is the adsorption capacitance.

\section{RESULTS AND DISCUSSION}

The deformation curves $\sigma-\varepsilon$ obtained in our experiments are linear-elastic dependencies up to the complete sample fracture when the ultimate strength is reached. The deformation curves are similar for all the charcoal brands under study. Fig. 2 shows that the fracture occurs along the load axis. These data coincide with the results of a detailed study on the nature of fragile material fracture reported in refs. [9-12], which shows a scale invariance of the fracture process based on the concept of the self-similarity of the process beginning from the scale of the order of the crystal lattice period and extending to the ever greater spatial dimensions. Within the theme of this review, the fracture is a sequence of catastrophes (formation of defects of increasing magnitude) throughout the scale hierarchy up to the macroscopic scale with the formation of a main crack and sample deformation.

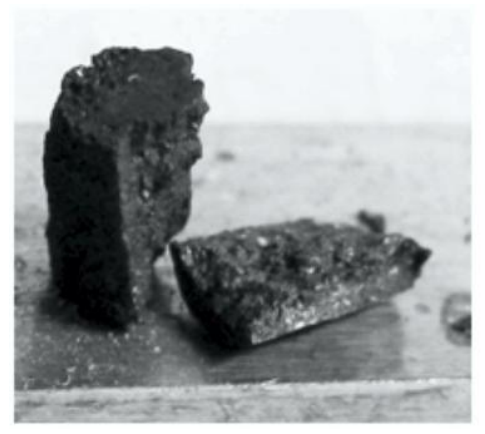

ISQ DON GW4

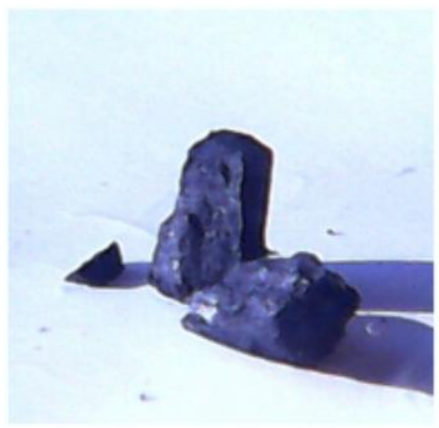

C40/4 EXTRA KJ

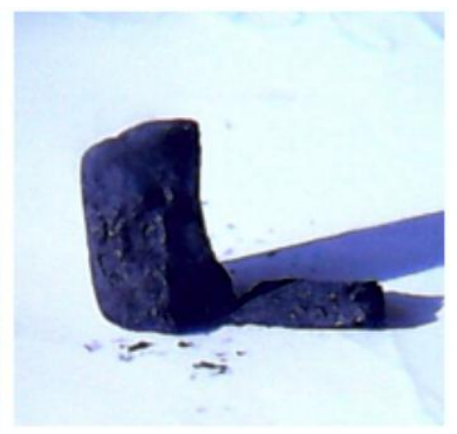

Norit RKJ4

Fig. 2. Typical fracture pattern of the charcoals

Tables 1-3 present the mechanical and adsorption characteristics of investigated charcoal brands: $\bar{\sigma}-$ average ultimate strength; $\lambda$ - relative error of ultimate strength measurements; $a$ - adsorption capacitance; $\rho-$ density. 
Charcoal ISQ DON GW4

\begin{tabular}{|c|l|c|c|c|c|}
\hline No & \multicolumn{1}{|c|}{ State } & $\begin{array}{c}\bar{\sigma}, \\
\mathrm{MPa}\end{array}$ & $\begin{array}{c}\lambda, \\
\%\end{array}$ & $\begin{array}{c}a, \\
\mathrm{mg} / \mathrm{g}\end{array}$ & $\begin{array}{c}\rho, \\
\mathrm{g} / \mathrm{cm}^{3}\end{array}$ \\
\hline 1 & Dehydratation & 24.1 & $\sim 8.4$ & - & 0.77 \\
\hline 2 & $\begin{array}{l}\mathrm{H}_{2} \mathrm{O} \text { vapor } \\
\text { saturation (initial) }\end{array}$ & 22.9 & $\sim 6.1$ & 190 & 0.89 \\
\hline 3 & $\begin{array}{l}\mathrm{H}_{2} \mathrm{O}+\mathrm{I}_{2} \text { vapor } \\
\text { saturation }\end{array}$ & 14.8 & $\sim 7.3$ & 480 & 1.14 \\
\hline 4 & $\mathrm{I}_{2}$ vapor saturation & 14.3 & $\sim 6.0$ & 770 & 1.37 \\
\hline
\end{tabular}

Table 3

Charcoal Norit RKJ4

\begin{tabular}{|c|l|c|c|c|c|}
\hline No & \multicolumn{1}{|c|}{ State } & $\begin{array}{c}\bar{\sigma}, \\
\mathrm{MPa}\end{array}$ & $\begin{array}{c}\lambda, \\
\%\end{array}$ & $\begin{array}{c}a, \\
\mathrm{mg} / \mathrm{g}\end{array}$ & $\begin{array}{c}\rho, \\
\mathrm{g} / \mathrm{cm}^{3}\end{array}$ \\
\hline 1 & Dehydratation & 14.10 & $\sim 4.0$ & - & 0.67 \\
\hline 2 & $\begin{array}{l}\mathrm{H}_{2} \mathrm{O} \text { vapor } \\
\text { saturation (initial) }\end{array}$ & 12.28 & $\sim 5.6$ & 170 & 0.79 \\
\hline 3 & $\begin{array}{l}\mathrm{H}_{2} \mathrm{O}+\mathrm{I}_{2} \text { vapor } \\
\text { saturation }\end{array}$ & 12.16 & $\sim 3.0$ & 480 & 1.17 \\
\hline 4 & $\mathrm{I}_{2}$ vapor saturation & 10.60 & $\sim 2.5$ & 1100 & 1.41 \\
\hline
\end{tabular}

Charcoal C40/4 EXTRA KJ

\begin{tabular}{|c|l|c|c|c|c|}
\hline No & \multicolumn{1}{|c|}{ State } & $\begin{array}{c}\bar{\sigma}, \\
\mathrm{MPa}\end{array}$ & $\begin{array}{c}\lambda, \\
\%\end{array}$ & $\begin{array}{c}a, \\
\mathrm{mg} / \mathrm{g}\end{array}$ & $\begin{array}{c}\rho, \\
\mathrm{g} / \mathrm{cm}^{3}\end{array}$ \\
\hline 1 & Dehydratation & 16.50 & $\sim 1.0$ & - & 0.72 \\
\hline 2 & $\begin{array}{l}\mathrm{H}_{2} \mathrm{O} \text { vapor } \\
\text { saturation (initial) }\end{array}$ & 14.80 & $\sim 1.6$ & 88 & 0.79 \\
\hline 3 & $\begin{array}{l}\mathrm{H}_{2} \mathrm{O}+\mathrm{I}_{2} \text { vapor } \\
\text { saturation }\end{array}$ & 13.19 & $\sim 2.7$ & 490 & 1.18 \\
\hline 4 & $\mathrm{I}_{2}$ vapor saturation & 12.75 & $\sim 3.0$ & 950 & 1.40 \\
\hline
\end{tabular}

The histograms in Fig. 3 show the charcoal strength decrease due to the adsorption. One can see that compared to charcoal ISQ DON GW4, charcoals C40/4 EXTRA KJ, and Norit RKJ4 have a greater strength loss as a consequence of water vapor saturation.

Active charcoals, as industrial sorbents, have some peculiarities, determined by the nature of their surface and porous structure. The carbon crystallite surface is electrically neutral and the adsorption on the charcoal is mainly determined by the dispersion interaction forces.
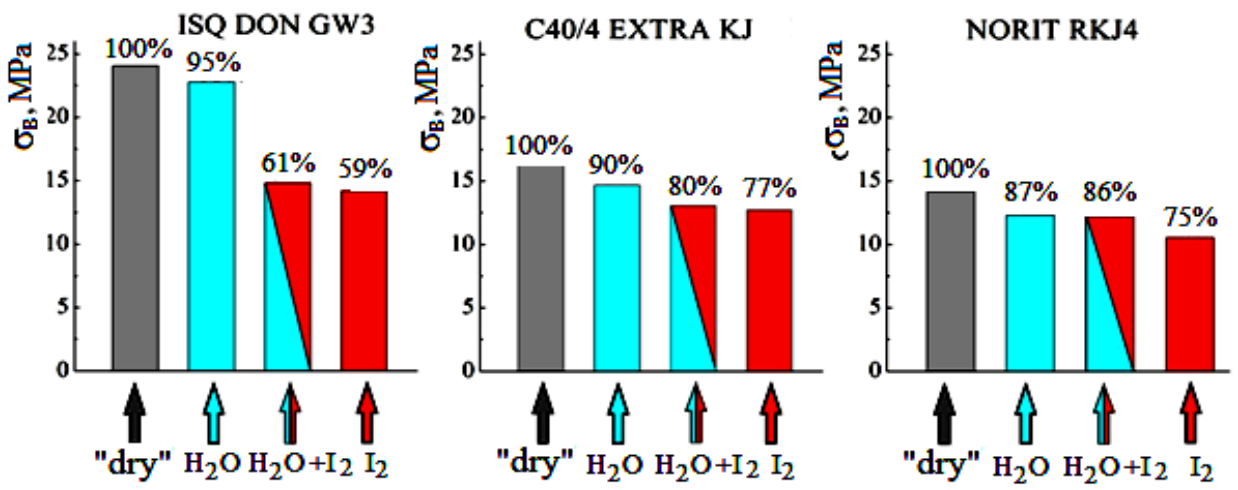

Fig. 3. Histograms of mechanical properties

Usually the charcoal structure comprises a gamma of pores of various sizes, and the adsorption capacitance and adsorption rate of industrial gas components is determined by the micropore content in the mass unit or in the granule volume. The water adsorption on charcoals occurs by an unconventional mechanism. Isotherms of water adsorption on the activated charcoals have a concave shape and are referred to the 3nd type isotherms by the IUPAC classification [13]. Isotherms of such type are characteristic for the adsorption when the adsorbat-adsorbat interaction is stronger than the adsorbat-adsorbent interaction. Dispersion forces of the interaction between the water molecules and carbon surface are very weak. The initial sections of the water isotherm are determined by its adsorption on the charcoal-surface chemisorbed strong oxygen-containing radicals, so-called primary surface adsorption centers (SAC) [14]. The water molecules are adsorbed, for the most part, on these centers, which form with them hydrogen bonds, shown in the papers on IR-spectroscopy [15]. The presence of primary adsorption centers, with which the water molecules form hydrogen bonds, leads to the restriction of the translation and rotary motion of water molecules. The water molecules, adsorbed on these centers, are secondary adsorption centers on which the adsorption of additional water molecules occurs due to the hydrogen bonds.

The state of adsorbate in the typical activated charcoal micropores forms upon adsorption a loose molecule packing, shown in Fig. 4 [14].

According to the proposed water vapor adsorption mechanism [16] in the carbon adsorbent the two- and three-dimensional clusters can be formed from the hydrogen-bond coordinated water molecules. Depending on the ratio of the pore width to distance between PAC, the clusters will grow, independently of one another, up to some limiting value, and then they will join by forming the bridges with the clusters adsorbed on the same or opposite micropore sides. At the same time, the bridging of some micropores occurs and they become inaccessible for other adsorbate molecules to be adsorbed in them. The pore bridging and forming of a loose openwork adsorbed water structure can explain the fact that upon calculating the adsorption carbon adsorbent volumes from the water vapor adsorption isotherms one obtains decreased values of limit sorption pore volumes as compared to the calculation from the adsorption isotherms of other substances, e.g. benzene [17], nitrogen [15]. 


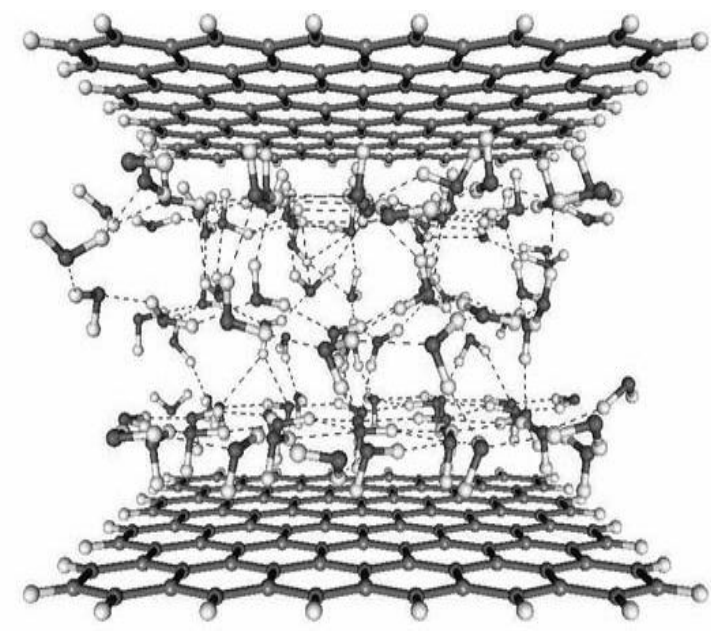

Fig. 4. Packing of 98 water molecules in the micropore of $1.2 \mathrm{~nm}$ width at $T=298 \mathrm{~K}$.

The dotted lines show the hydrogen bonds [14]

The aforesaid explains the result of a little water adsorption capacitance of the samples investigated, as well as a significant iodine adsorption capacitance increase after regeneration of charcoals and removal from them moisture and other adsorbates (see No 3, 4 in the Tables). As is seen from the tables, the average ultimate strength of all the charcoal brands decreases as follows: dehydrated charcoals $\rightarrow$ initial charcoals (water vapor saturated) $\rightarrow$ iodine vapor saturated charcoals without moisture removal $\rightarrow$ iodine vapor saturated charcoals after dehidronanion. Such a sequence confirms the Rehbinder effect (adsorption strength decrease), and in all that the iodine plays a determining role in the effect manifestation. This can be explained by the fact that the iodine molecules interact more strongly with the porous charcoal structure as compared to water. Indeed, it is well known that activated charcoals are selective adsorbents of substances the molecule of which have a high polarizability and large mass [2]. The highest strength for all the modes of sample saturation with adsorbate (No 1 to 4 in the Tables) is characteristic for ISQ DON GW4 charcoals and the lowest strength have Norit RKJ4 charcoals. However, if the charcoals advantage is estimated by the iodine adsorption capacitance, the preference should be given to Norit RKJ4 charcoals (see Table 3). An intermediate position among the charcoals investigated is taken by the brand C40/4 EXTRA KJ, having a sufficient strength and high adsorption capacitance. The lesser relative errors in the ultimate strength measurements evidence on a higher homogeneity of C40/4 EXTRA KJ charcoals.

From the general reasoning it is clear that the mechanical strength of coal, determined during compression tests, is similar to the value of strength $\mathrm{P}$, determined by the method of abrasion. This position is confirmed by a comparison for the C40/4 EXTRA KJ and NORIT RKJ4 coals of the data presented in $[18,19]$ and the results of the studies. In the initial state, C40/4 EXTRA KJ and NORIT RKJ4 coals are characterized by $\Pi=88.5$ and $78 \%[18,19]$ versus $\bar{\sigma}=14.80$ and $12.28 \mathrm{MPa}$ (see Tables 2 and 3, respectively). Under real operating conditions, charcoal filters in the NPP air discharge purification systems (ventilation systems) are subjected to more severe abrasion of charcoal at the top of the adsorber, which is most saturated with iodine and methyl iodide impurities. Taking into consideration the data obtained, it may be recommended that activated charcoal be tested not in the delivery state, when there is a rather long stay in the environment, but in the state of saturation with iodine and methyl iodide vapors.

\section{CONCLUSION}

The strength characteristics of the granular activate charcoal of brands ISQ DON GW4, C40/4 EXTRA KJ, and Norit RKJ4 in various states: initial (saturated with $\mathrm{H}_{2} \mathrm{O}$ vapor due to the long storage), dehydrated, saturated with $\mathrm{I}_{2}$ vapor, saturated with $\mathrm{H}_{2} \mathrm{O}$ vapor and saturated with $\mathrm{H}_{2} \mathrm{O}+\mathrm{I}_{2}$ were investigated.

It has been found that a significant $(25 \ldots 40 \%)$ decrease in the fracture stress of activated charcoal of different producers (ISQ DON GW4, C40/4 EXTRA KJ, Norit RKJ4) occurs as a result of iodine vapor saturation that is associated with the manifestation of the Rehbinder effect, i.e. adsorption strength decrease. The degree of charcoal fracture due to the water vapor saturation is significantly less $(5 \ldots 13 \%)$.

The adsorption decrease in the mechanical stability of charcoal sorbents should be taken into account when selecting them for filters of NPP air discharge purification systems (ventilation systems).

\section{REFERENCES}

1. Chemistry and technology for the production of the main chemical industry: Collected articles of NIOKHIM / Ed. by V.F. Anapolsky. Kharkov: NIOKHIM, 1998, v. 71, p. 66.

2. N.V. Keltsev. Fundamentals of adsorption technology. M.: "Khimiya", 1984, p. 592.

3. A.A. Kharchev, A.V. Obruchikov, S.M. Lebedev. Influence of the operation time of iodide sorbent on its radioactive methyl iodide adsorption capacitance // Uspekhi Khimicheskikh Tekhnologij. 2011, v. XXV, N 6(122), p. 95-99 (in Russian).

4. F. Ren, E.D. Case, A. Morrison, et al. // Philosoph. Mag. 2009, v. 89, N 14, p. 1163-1182.

5. Yu.P. Stefanov. Localization of deformation and fracture in geomaterials. Numerical simulation // Fizicheskaya Mesomekhanika. 2002, N 5, p. 107-118 (in Russian).

6. I.V. Lepin, T.K. Grigorova, V.I. Sokolenko. Adsorption decrease in the strength of sorbents and catalists // Problems of Atomic Science and Technology. 2018, N 2, p. 87-91.

7. V.F. Kononyuk, A.I. Sakharov, M.M. Dubinin Dilatometric investigation of $\mathrm{NaA}$ zeolite under conditions of water vapor adsorption // Doklady AS USSR. 1971, v. 198, p. 638 (in Russian).

8. A.V. Tvardovskiy. Sorbent Deformation. Academic Press / Elsevier: Amsterdam, Boston, London etc. $2006,286 \mathrm{p}$.

9. P.V. Makarov, A.A. Trubitsin, S.P. Voroshilov. Self-similarity of carbon fracture and evolution of loaded solids and media // Ugol'. 2006, N 10, p. 55-58 (in Russian). 
10. P.V. Makarov. Mathematical theory of loaded solids and media // Fizicheskaya Mesomekhanika. 2008, v. 11, N 3, p. 19-35 (in Russian).

11. P.V. Makarov. The evolutionary nature of block organization of geomaterials and geo-media. Universal criterion of fractal delirium divisibility // Geologiya $i$ geofizika. 2007, v. 48, N 7, p. 724-746 (in Russian).

12. P.V. Makarov, N.B. Karpenko, I.Yu. Smolin, Yu.P. Stefanov, V.A. Tunda, A.N. Khomyakov. Studying the deformation and destruction of geomaterials and geomedia as hierarchical systems // Fizicheskaya Mesomekhanika. 2005, v. 8, special issue, p. 17-20 (in Russian).

13. K.S.W. Sing, D.H. Everett, R.A.W. Haul, L. Moscou, R.A. Pierotti, J. Rouquerol, T. Siemieniewska. Reporting physisorption data for gas/solid systems // Pure and Applied Chemistry. 1985, v. 57(4), p. 603-619.

14. A.S. Spiridonov, G.O. Khondar', A.M. Tolmachev. Molecular structures of adsorbed water // Kolloid. Zhurnal. 2011, v. 73, N 5, p. 686-694 (in Russian).
15. R.H. Bradley, B. Rand. A comparison of the adsorption behaviour of nitrogen, alcohols and water towards active carbons // Carbon. 1991, v. 29, p. 11651172 .

16. R.Sh. Vartapetyan, A.M. Voloshchuk. Mechanism of water molecule adsorption on carbon adsorbents // Uspekhi Khimii. 1995, v. 64, N 11, p. 1055-1072 (in Russian).

17. V.V. Guryanov, M.M. Dubinin, M.S. Misin // Zhurnal Fizicheskoj Khimii. 1976, v. 50, N 10, p. 203208 (in Russian).

18. V.G. Kolobrodov, V.I. Sokolenko, E.I. Vinokurov, T.K. Grigorova, R.M. Sibilyova, M.A. Khazhmuradov. Mechanical-resistance measurements of adsorbens intended for renovation OF AU-1500 adsorbers of NPP airdischarge purification systems // Problems of Atomic Science and Technology. 2011, N 6, p. 76-78.

19. V.I. Sokolenko, M.A. Khazhmuradov, E.I. Vinokurov, T.K. Grigorova, R.M. Sibileva, D.V. Sharuda. Study complex of properties of the adsorbent for renewal filters of ventilation systems NPP // Problems of Atomic Science and Technology. 2014, N 2, p. 85-88.

Article received 27.12.2019

\title{
СРАВНИТЕЛЬНЫЕ ХАРАКТЕРИСТИКИ МЕХАНИЧЕСКИХ И АДСОРБЦИОННЫХ СВОЙСТВ АКТИВНЫХ УГЛЕЙ ДЛЯ АДСОРБЕРОВ СИСТЕМ ВЕНТИЛЯЦИИ АЭС
}

\author{
И.В. Лепин, Р.М. Сибилева, В.И. Соколенко, Э.И. Винокуров, М.А. Григоренко
}

Представлены результаты исследований прочностных и адсорбционных характеристик гранулированных активных углей марок ISQ DON GW4, C40/4 EXTRA KJ и Norit RKJ4. Измерялся предел прочности образцов в различных состояниях: исходном (насыщение парами $\mathrm{H}_{2} \mathrm{O}$ вследствие длительного хранения), обезвоженном, насыщенном парами $\mathrm{I}_{2}$ и $\mathrm{H}_{2} \mathrm{O}+\mathrm{I}_{2}$. Установлено сильное $(25 \ldots 40 \%)$ снижение напряжения разрушения активных углей в результате насыщения парами йода, что связано с проявлением эффекта Ребиндера. Степень адсорбционного снижения механической устойчивости сорбентов необходимо учитывать при их отборе для воздушных фильтров систем вентиляции АЭС.

\section{ПОРІВНЯЛЬНІ ХАРАКТЕРИСТИКИ МЕХАНІЧНИХ І АДСОРБЦІЙНИХ ВЛАСТИВОСТЕЙ АКТИВНОГО ВУГІЛЛЯ ДЛЯ АДСОРБЕРІВ СИСТЕМ ВЕНТИЛЯЦІї АЕС}

\section{І.В. Лєпін, Р.М. Сібілєва, В.І. Соколенко, Е.І. Винокуров, М.А. Григоренко}

Представлено результати досліджень міцності і адсорбційних характеристик гранульованого активного вугілля марок ISQ DON GW4, C40/4 EXTRA KJ i Norit RKJ4. Вимірювалася межа міцності зразків у різних станах: вихідному (насичення парами $\mathrm{H}_{2} \mathrm{O}$ внаслідок тривалого зберігання), після видалення вологи, насиченому парами $\mathrm{I}_{2}$ i $\mathrm{H}_{2} \mathrm{O}+\mathrm{I}_{2}$. Встановлено сильне $(25 \ldots 40 \%)$ зниження напруги руйнування активного вугілля в результаті насичення парами йоду, що пов'язане 3 проявом ефекту Ребіндера. Ступінь адсорбційного зниження механічної стійкості сорбентів необхідно враховувати при їх відборі для повітряних фільтрів систем вентиляції АЕС. 